\title{
AEROMAGNETIC MAP OF THE GEORGIAVILLE QUADRANGLE, PROVIDENCE COUNTY, RHODE ISLAND
}

\author{
GEOPHYSICAL INVESTIGATIONS \\ MAP GP- 779
}

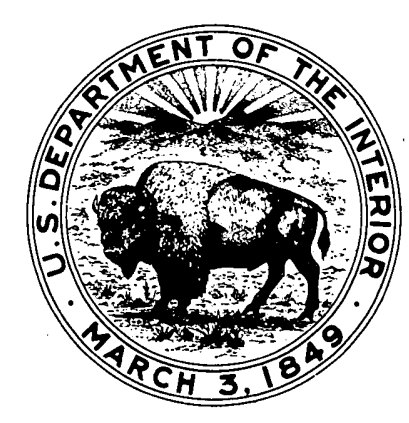

PUBLISHED BY THE U.S. GEOLOGICAL SURVEY 